\title{
Research Article: Adoption of vermicomposting technology by farmers of Gulbarga district in Karnataka
}

\author{
SHREEDEVI A. SANKARATTI AND S.N. HANCHINAL
}

Article Chronicle : Received :

25.08.2017;

Revised :

17.09.2017;

Accepted :

04.10.2017

KEY WoRDS:

Adoption,

Correlation,

Vermicomposting
SUMMARY : The present study was conducted in Gulbarga district of Karnataka during the year 201213. Based on highest number of vermicomposting pits, four taluks namely Gulbarga, Jewargi, Aland and Afazalpur were purposively selected and from each taluk, two villages were selected and from each village, fifteen farmers were selected randomly. Thus, the total sample size constitutes 120 respondents for the study. The ex-post facto research design was used for the study. The data were collected using pre-tested structured interview schedule personally. The collected data were analyzed using appropriate statistical tools. The results of the study revealed that, about 70 per cent of the farmers were between medium to high knowledge category about vermicomposting and majority of them were having knowledge in recommended pit size, pre decomposition of raw material before filling pits and management of ants and termites. More than 70 per cent of the farmers belonged to high adopter category. More than 80 per cent of farmers adopted the recommended practices like the chemical used for pest management, size of the pit and dosage of chemical used for management of ants and termites. The independent variables like land holding, extension participation, mass media utilization of the farmers had shown the positive and significant relationship with their knowledge level and land holding, annual income and scientific orientation exhibited positive and significant relationship with their adoption level

How to cite this article : Sankaratti, Shreedevi A. and Hanchinal, S.N. (2017). Adoption of vermicomposting technology by farmers of Gulbarga district in Karnataka. Agric. Update, 12(4): 639-642; DOI : 10.15740/HAS/ AU/12.4/639-642.
Author for correspondence :

\section{SHREEDEVI A.}

SANKARATTI

Department of

Agricultural Extension Education, College of Agriculture, University of Agricultural Sciences, RAICHUR (KARNATAKA) INDIA

Email:shridevi.sankaratti@ gmail.com

See end of the article for authors' affiliations 